\title{
Fulfilment in Matthew
}

F P Viljoen

(North west University - Potchefstroom campus)

\section{ABSTRACT}

\section{Fulfilment in Matthew}

Matthew extensively explored the motif that Jesus was the fulfilment of the Old Testament hopes. In this article investigation is done on the way Matthew employs this motif. The expression of fulfilment of Scripture had an important function in early Christian circles. The Christian faith had to be legitimatized by reference to the Jewish Scriptures. What happened to Jesus and the rise of the Christian church were to be identified as the fulfilment of the promises of the Old Testament. For today's reader it seems as if Matthew sometimes draws awkward links between Old Testament citations and their fulfilment in Jesus. However, when his hermeneutical method is being mirrored against contemporary interpretative methods, it becomes clear that Matthew used the fulfilment motif in a then acceptable way to strategically and persuasively place Jesus' ministry within the unfolding plan of God.

\section{INTRODUCTION}

Scholars have recognized that the theme of fulfilment plays a central motif in Matthew's Gospel. More than 50 years ago (1952) this theme already has been identified by $\mathrm{C} \mathrm{H}$ Dodd in his book According to the Scriptures: The substructure of New Testament Theology. This theme was further explored by B. Lindars in New Testament Apologetic: The Doctrinal significance of the Old Testament Quotations (1961). Another influential article on this theme came from Moule (1967/8: 293-320) Fulfilment words in the New Testament: Use and abuse. From these studies it is clear that all Christian writers of the first century in some way or another indicated that Jesus was the fulfilment of the Old Testament hopes ${ }^{1}$. However, while other New Testament writers quoted a few obvious texts as fulfilled in Jesus, Matthew explored this motif extensively

1 "The life, death and resurrection of Jesus became for early Christians the hermeneutical key for the interpretation and application of Jewish Scriptures" (Evans 2004:145). 
(Davies \& Allison 2004a:211; Versteeg 1980:23). France (1998:167) labels fulfilment as "the special trademark" of this Gospel.

Although the motif of fulfilment in early Christian writings has often been recognized, the intention of this article is to explore the function of this theme for the understanding of the Matthean Gospel. The hunch of this investigation is that Matthew employs this motif very systematically in placing the ministry of Jesus within the unfolding plan of God. This theme affects his presentation of the story of Jesus.

\section{FORMULAIC PHRASE "THAT IT MIGHT BE FUL- FILLED”}

The introductory clause "to fulfill (or "then was fulfilled" $\left.{ }^{2 "}\right)^{3}$ what had been spoken by the prophet, saying ..."4 has come to be distinguished as Matthew's "formula-quotations". There is broad consensus that the introductory formulaic phrase comes from the evangelist in his redaction of sources ${ }^{6}$.

At least ten references ${ }^{7}$ to the Old Testament are introduced by these words:

2 In Mt. 2:17 and 27:9-10 Matthew uses the temporal Tót€ to replace the purposive ì $v$.

3 Matthew uses $\pi \lambda \eta \rho$ ó$\omega$ (fulfil) of Scriptures 12 times in comparison to once by Mark and twice by Luke (Davies \& Allison 2004a:76).

4 The formula varies slightly, sometimes mentioning the name of a prophet, or referring to prophets in the plural of omitting "saying", or specifying that it was the Lord who spoke through the prophet.

5 In other gospels the concept of fulfilment is also present, however without the terminology of fulfilment.

6 One should, however, consider the fact that Matthew reports for example that the angel used the formula quotation in Mt. 1:22. Some scholars such as Van Bruggen (1990:42) therefore conclude that this phrase does not come from the evangelist himself, but directly from the angel.

7 Scholars are not in complete agreement on the number of fulfilment citations. Some scholars also include Mt. 2:6 and 26:56 (Soares Prabhu 1976:41). The distinction of the formula quotations from the remaining Old Testament quotations is not unambiguous as the introductory formulas of several other quotations are very similar. "The formula quotations thus are not an absolutely special case within the Matthean Old Testament quotations; there are gradations to the 'normal' quotations" (Luz 1990:156). 
- four in the first two chapters, the story of Jesus' birth and childhood (Mt. 1:22-23 (= Is. 7:14), 2:15 (= Hs. 11:1); 2:17-18 $(=\mathrm{Jr} .31: 15) ; 2: 23)^{8}$;

- four again in the section that describes Jesus' public ministry outside Jerusalem (Mt. 4:14-16 (= Is. 8:23-9:1); 8:17 (= Is. 53:4); 12:17-21 (= Is. 42:1-4); 13:35 (Ps. 78:2)); and

- two in the chapters that cover the passion week (Mt. 21:4-5 (= Is. 62:11; Zch. 9:9); 27:9-10 (Zch. 11:12-13; Jr. 18:3; 59:6-9).

Matthew uses the majority of fulfilment citations before the passion narrative, pointing out that prophecies had already been fulfilled in the life and work of Jesus. In addition to these there are some 35 other citations with different introductory clauses, as well as a large number of indirect quotations from or allusions to the Old Testament ${ }^{9}$. Ellis (1991:82) suggests that introductory formulas reveal something of the theological convictions of a New Testament writer. Obviously Matthew wants to depict Jesus as the One who fulfills the Jewish prophecies (Combrink 1997:58).

Although the concept of fulfilment occurs implicitly in many New Testament writings (Menken 2003, 181), similar explicit formulae are surprisingly absent from other Jewish and Christian literature of the period ${ }^{10}$. The only significant parallel is John's use of the formula "that the scripture might be fulfilled" or the like in six occasions (Jn. 12:38; 13:18; 15:25; 17:12; 19:24, 36) ${ }^{11}$.

8 It is difficult to identify the passage Matthew refers to. The plural

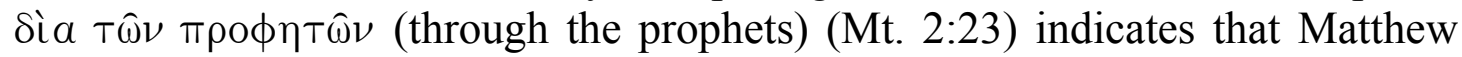
probably was not able to identify the quotation which he received. It is similar with Mt. 13:35. Possibly a copy of the Minor Prophets was not accessible to the evangelist. This situation confirmed that the Matthean community no longer lived within the synagogue union (Luz 1990:157).

9 It is not possible to give an exact number as the variation in use ranges form a definite quotation introduced by a clear fulfilment quotation on the one hand and a vague allusion or echo of a text on another. In some cases it is difficult to know if one is hearing an echo at all or perhaps imagining it (cf. Hays 1989:23 and Van der Walt 1962:230).

10 Obermann (1996:348-350) distinguishes between the "implicit" and "explicit" fulfilment of Scripture.

11 Similar formulae occur in Mt. 2:5-6; 13:14; 26:54, 56. 
Speaking of the "fulfilling" of oral or written utterances evidently is a metaphorical way of speaking. The basic idea is that words are empty and that they have to be filled. Jesus filled the words of Scripture. Before his coming the words of Scripture presented a promise of something that was to come (Menken 2003, 185). The idea behind this way of speaking is already expressed in Old Testament passages such as Numbers 23:19 ("Does he (God) promise and not fulfill?") and Isaiah 55:11 ("So is my word that goes out of my mouth: It does not return to me empty, but will accomplish what I desire and achieve the purpose for which I sent it"). The evangelist, who was bound to tradition, did not "invent" this idea (Luz 1990:158). In the New Testament "fulfilment" marks the time when God acts in realizing his promises. The "fulfilment" marks the time of the end as God's eschatological fulfilment. It is the eschaton that fills the empty words with reality and Jesus is God's eschatological envoy.

The fulfilment formula has a rather solemn character evoking a sense of awe. The formula prepares the reader for a solemn declaration of how God's previously announced purpose has reached its due conclusion in Jesus (France 1998:172).

Stendahl (1968) pointed out that the use of Scripture in Matthew shows remarkable similarities to the Pesher-commentaries among the Dead Sea Scrolls, especially the Habakkuk-commentary (1QpHab). Stendahl's main interest was the contextual interpretation of the prophetic words which influenced the change of the quotations. However, reference to the Pesher-commentaries does not fit Matthew's changes in the reproduction of the texts. Scripture in Matthew is not used primarily as prediction, which can now be fulfilled. Rather, the Jesus-events interpret Scripture in such a way as to give it a new meaning. By the revelation in Jesus the real meaning of the text is disclosed (Müller 2001:321). In contrast to the introductory word $\pi \lambda \eta \rho o ́ \omega$ in Matthew's fulfilment quotations, it is noteworthy that the interpretation of the prophets by the Qumran community which referred to their present time was introduced by pesher (interpretation) which is absent in Matthew (Luz 1990, 158). There are important differences between these words. Pesher begins with the text and interprets it, while the $\pi \lambda \eta \rho$ ó $\omega$ motif begins with the historical event in the time of Jesus and understands it as the fulfilment of predictions. Pesher therefore starts with the Jewish 
Bible and tries to understand it, while $\pi \lambda \eta \rho$ ó $\omega$ motif in Matthew begins with the present and reflects on it the light of the biblical text.

\section{DISTRIBUTION OF THE FULFILMENT QUOTATIONS}

The distribution of the fulfilment quotations in the Gospel seems to be unbalanced.

Taking a closer look it becomes clear that Matthew added the fulfilment quotations at strategic points in his Gospel (Menken 2003: 197):

- The concentration in Matthew 1 and 2 is striking, where the formula are notably frequent. In this prologue (Jesus' birth and childhood) the evangelist offered material not yet found in Mark or Q. He probably added several fulfilment quotations in this section to assert the new material. In the prologue the evangelist introduces accents which are important for the whole of the Gospel and which the reader should keep in mind when examining the entire Gospel (Luz 1990:162).

- When describing Jesus' public ministry Matthew adds fulfilment quotations right at the beginning of Jesus' public ministry to account for his work in Galilee (Mt. 4:14-16), at the end of a summary of Jesus' healing activity (Mt. 8:17), at the end of another summary in which traits of Jesus' ministry are described (Mt. 12:17-21), and at the end of a summary of his teaching in parables (Mt. 13:35). These four quotations are all ascribed to Isaiah, although the quotation in Matthew 13:35 actually comes from Psalm 78:2.

- In the narrative of the passion Matthew adopted and expanded material from Mark and added two fulfilment quotations, one at the beginning and one at the end of the section. As far as sources are concerned the fulfilment quotations in Matthew $8: 17 ; 12-18-21 ; 13: 35$ and $21: 4$ are inserted. The rest of the fulfilment citations are found in material that is unique to Matthew (Luz 1990:156).

\section{FUNCTION OF THE FULFILMENT PHRASE}

Early Christianity started as a community of interpretation within the context of early Judaism (Müller 2001:315). The expression of fulfilment of Scripture had an important function in communication between Christians. The Christian faith had to be legitimatized by reference to Scripture. What happened to Jesus and the rise of the 
Christian church were to be identified as the fulfilment of the promises of the Jewish Bible.

Gloer (1991:3) finds four reasons why the New Testament writers in general used the Old Testament:

- “(1) to demonstrate that Jesus is the fulfilment of God's purposes and of the prophetic witness of the Old Testament Scriptures ...

- (2) as a source of ethical instruction and edification of the church ...

- (3) to interpret contemporary events ...

- (4) to prove a point on the assumption that the Scripture is God's Word".

The first and third of these identified reasons are specifically applicable to Matthew.

In Matthew the fulfilment quotations functioned internally and externally. Internally "the earliest use of the Scriptures was rather to understand the gospel, to clarify the implications of faith in Jesus for one's relationship with Israel's God and with the world" (Juel 1988:1). Ad extra the concept was also used in external communication between Christians and non-Christians, mainly in an apologetic function (Combrink 1997:72, 79). The theological activity of the early church started with a collection of Old Testament passages used in apologetics against Jews (Albl 1999:8). Christians utilized the expression to answer criticism brought in against their convictions about Jesus. One should also recognize the missionary function of the expression by which people were attracted to join a group (Menken 2003:180). Christian Jews tried to convince their fellow Jews that God had decisively acted in Jesus of Nazareth by interpreting Jesus within the framework of Jewish Scriptures (Viljoen 2006a:152).

The Sitz im Leben of these fulfilment phrases $^{12}$ in Matthew should be interpreted in the context of an apology towards

12 When discussing the Sitz in Leben of expressions, one should distinguish three successive life-settings: the setting in the historical ministry of Jesus (Sitz im Leben Jesu), the setting in the restricted selection of Jesus' sayings in the Matthean community (Sitz im Leben der Kirche), and the setting in the Gospel 
accusations of Jews against the Matthean community (Viljoen 2006b:243). It has been increasingly recognized that the social context of Matthew is closely related to the author's relationship with Judaism (Keener 1999:45; Sim 1998:150). Matthew was writing in the painful situation of a Jew who followed Jesus and therefore experienced increasing tension with official Judaism. While the Matthean community initially tried to maintain good relations with the synagogue, the community was heading towards a break with the contemporary Judaism of the synagogue. Matthew reacted to counter Jewish suspicion against their conviction that Jesus was the Messiah (Loader 1997:167). Following Jesus resulted in the alienation between the Matthean community and the synagogue. To be in tension with the synagogue was not only a religious matter. It meant estrangement from one's people and community ${ }^{13}$. It is commonly assumed that this tension could be linked with the introduction of the Birkath ha-Minim around 85 C.E. (e.g. Burridge 1994:91). The so called Birkath ha-Minim was introduced into the Jewish synagogue liturgy, referring to a phrase in the Eighteen Benedictions which were supposed to be recited three times daily by all Jews:

"Let Nazarenes (Christians) and minim (heretics) perish in a moment, let them be blotted out of the book of the living, and let them not be written with the righteous" (as quoted by France 1998:85).

It is relatively sure that Matthew was composed in the period in which this Jewish benediction was first formulated. This must have had a significant impact upon Jewish-Christian relations (Horbury 1982:19-61). Matthew's community struggled to make sense of this pain and hostility. The Gospel was meant to provide a context for making sense of the past and as a direction to shape the presence and the future of the community that found itself on the margins of the rest of the Jewish community (Carter 2000:33).

of Matthew (Sitz im Leben der Evangelium). The last setting is immediately accessible to us.

13 Matthew uses the phrase "their synagogue" five times $(4: 23 ; 9: 35 ; 10: 17$; $12: 9 ; 13: 54)$ and "your synagogue" once $(23: 34)$ to underline the distance between Jesus and the synagogue community (Carter 2000:31). 
For Matthew's argument it was important to defend his conviction that Jesus was the fulfilment of God's plan with his people (Versteeg 1980:23). Luz (1990:163) formulated this meaningfully: "In the situation in which Israel and the Christian community are in confrontation as two definitively separated hostile brothers, each brother was determined to claim the whole heritage of the fathers explicitly and fundamentally for himself'. In defending his community's convictions, Matthew found it important to present the life of Jesus in all its aspects within the context of the fulfilment of Scripture.

\section{BASED ON MUTUAL ACKNOWLEDGEMENTS}

To be effective, argumentation based on fulfilment quotation presupposes that both the author and the audience acknowledged the Jewish Scriptures as authoritative, divine revelation (Combrink 1997:79; Keener 1999:87; Menken 2003:186). The argumentation of fulfilment citations is based on demonstrating the agreement between certain passages from the Jewish Scriptures and what happened to Jesus. Matthew tried to convince the Jews that Jesus of Nazareth was God's eschatological messenger by demonstrating that the Old Testament passages were fulfilled in what Jesus said and did, and what happened to Him.

Matthew and his audience also must have shared the conviction that the eschatological fulfilment of Scripture was necessary. The Jewish Scriptures contain words that had been spoken by God in the past that were waiting to be fulfilled in the end time.

\section{WORDING OF THE QUOTATIONS}

The text form of most of the quotations is remarkable. Menken (2003:15) remarks that "Matthew's fulfilment quotations are notorious for their peculiar textual form". Some are closer to the Masoretic text than to the LXX, while some show influence from other Greek translations and Targums (Luz 1990:159). When sharing material with the other Synoptics Matthew usually gives the LXX in direct quotations of the Old Testament. However, when looking at the eleven formula quotations, the only one that offers a similar text as the $\mathrm{LXX}^{14}$ is 1:23 (except for the change from "you will be

14 The idea of a single "authorized" version of the LXX in the first century is an anachronism. 
called" to "they will call"). In all the others the text differs substantially from the LXX (France 1998:173). Most scholars seem to think that the evangelist used his own abbreviated translation of the Hebrew text, possibly with some LXX influence. Menken $(2004)^{15}$ made an extensive study of "Matthew's Bible" and came to the following conclusions on the texts forms of the formula quotations:

- Matthew 1:23: The quotation (from Is. 7:14) comes from a revised LXX. The revision ensures that the translation renders the Hebrew more correctly (Menken 2001a:158; 2003, 131).

- Matthew 2:15: The quotation (from Hs. 11:1) is closer to the Masoretic text than the LXX. This could be due to a revision of the LXX or a fresh translation of the original Hebrew, though this revision can hardly be distinguished from a fresh translation. This translation could be Matthew's own, or preMatthean (Menken 1999:86; 2003:135).

- Matthew 2:18: The quotation (from Jer. 31(38):15) offers a better translation of the Hebrew as that of the LXX, as well as an adaptation to the context of the verse in Jeremiah and the analogous verse Genesis 37:35 (Menken 2000:123; 2003:159).

- Matthew 2:23: This quotation apparently cannot be found in the Old Testament. Menken (2001b:467; 2003:177) regards Jdg. 13:5, 7 as the primary source of the quotation. Apparently Matthew saw some parallels between Jesus and Samson. The evangelist probably "composed" the fulfilment quotation with the help of an analogous verse.

- $\quad$ Matthew 4:14-16: The quotation (from Isa. 8:23-9:1) agrees in some points with the LXX, on other points with the Hebrew text, and in details it deviates from both. Matthew probably abbreviated the Old Testament text in view of the context into which he inserted the quotation. At the same time the quotation led him to make explicit some elements of the context that were only implicit in Mark (Menken 1998a:543; 2003:32).

15 This publication presents a compilation of previous published articles of Menken all related to formula quotations in Matthew. Bibliographical references to the latter are given in the following detailed analysis. 
- Matthew 8:17: The quotation (from Isa. 53:4) looks like a fairly exact translation of the Hebrew text and much more precise than the spiritualizing rendering of the LXX. Matthew makes the Hebrew word that indicates a he-donkey into a shedonkey which is essential to his application of this quotation (Menken 1997:325; 2003:48).

- Matthew 12:18-21: The quotation (from Isa. 42:1-4) deviates significantly from both the LXX and Hebrew text. It is also problematic that there is very limited connection between the events and the quotation. Matthew omitted from the Old Testament passage the one line that was not compatible with Jesus' passion and death (Menken 1998b:264; 2003:65).

- Matthew 13:35: Matthew ascribes the quotation from Psalm 78:2 to Isaiah. Matthew 13:35b however correlates with Isaiah 29:14 which the evangelist probably had in mind (Menken 2003:104).

- Matthew 21:4-5: The quotation (from Zch. 9:9) has been changed substantially. In fact, the first line of the quotation does not come from Zechariah but from Isaiah 62:11 and has been abbreviated. The Old Testament quotation and the Matthean context have mutually influenced each other (Menken 2003:106). These adaptations of the quotations are due to editorial work of the evangelist.

- Matthew 27:9-19: The quotation (from Zch. 11:12-13) presents a change in wording and sequence of lines, to attune it to the preceding narrative. In its Matthean text, the quotation is a typical ad hoc creation. Some details of the quotations have been derived not from Zechariah 11:12-13, but from other analogous Old Testament passages (Dt. 23:18-19 and Jr. 32(39):6-15) (Menken 2003:191) making it the most heavily edited fulfilment quotation. It was obviously so heavily edited to make it fit the narrative context (Menken 2003:199).

Some possibilities can be proposed to explain this inconstancy in wording of the quotations. It seems that when Matthew used Mark, the LXX was used in his fulfilment quotations. The LXX versions of the quotations in Matthew were therefore not Matthew using the LXX but rather Mark. With Matthew's own quotations which differ considerably from the LXX, various explanations have been proposed by scholars. It could be that Matthew adapted the LXX 
presenting an independent and free rendering of the LXX version of the passages concerned (Kooyman 1992:83; Slingerland 1979:25). Some assume that the quotations were derived from another (unknown) Greek translation used in Christian circles (Plummer 1982[1909]:47; Soares Prabhu 1976:83-84). It could also be that Matthew used an existing revised form of the LXX (Menken 2003:280). Others think that Matthew derived them from an extant collection of sources, or testimonies (although the existence of such a collection is uncertain as being discussed in the next section) in which it already had its striking form (Strecker 1971:63). Some scholars propose that Matthew had drawn his quotations from existing oral traditions (Luz 1990:161). However, it seems most probable that Matthew himself was responsible for changing the text. Matthew's own quotations from the Old Testament most probably came from other translations of the original Hebrew than the LXX which he apparently adapted to make it more clear how they have found their fulfilment in Jesus. Matthew takes the original meaning of the text as starting point of his interpretation, but then he locates its fulfilment in a new situation.

Gundry (1967:155-159) therefore named Matthew the "Targumist". The Aramaic Targums that have survived show that there was a living tradition of biblical translation (or interpretation) in which there was no sharp separation between text and interpretation. Extensive paraphrase and even interpolation were acceptable in order to bring out the perceived application of the quotation. Referring to Targums furthermore raises the possibility that one should not speak of "the Hebrew" and "the LXX" as the only textual resources available to Matthew. Matthew probably even had a wider variety of versions to choose from.

\section{ORIGIN OF FORMULA-QUOTATIONS}

The repetition of the striking formula and the unique textual trends of the formula quotations urge one to ask if they might have existed as some separate group of proof texts prior to Matthew's text. J R Harris introduced the "testament-book" theory in the beginning of the twentieth century with his publication of Testimonies (2 volumes, 1916-1920). Strecker (1971:50) picks up this argument in his reference to a Zitatensammlung which Matthew supposedly had used as source. 
The existence of such a proof text collection is unlikely. Firstly no such collection of testimonia in the sense of an apologetic book has yet been found ${ }^{16}$ (Keener 1999:87). Furthermore most of the texts Matthew uses are not used by other New Testament writers. These texts also do not show a unified textual method or hermeneutical approach. In an attempt to explain the revision of the Old Testament texts in Matthew's Gospel, France (1980/1:237) discusses the raison d'etre of the quotations. He indicates that Matthew's narrative is the motive for the selection and shaping of the Old Testament text. At the same time these texts have become the organizing principle for Matthew's narrative. Thus Matthew deliberately adapted the Old Testament texts in a "targumising" way to bring out the relevance of the text in its narrative context. Stanton (1985:1933) concludes that when Matthew took over Old Testament passages already known in Christian usage, he reproduced the familiar wording. But when he was the first to apply Old Testament as being fulfilled in the life of Jesus, he adapted the wording to best fit his purpose.

In his selection of versions and his reworking of the original it seems more likely that the distinct form of the formula quotations came from Matthew himself.

\section{MATTHEW'S WAY OF INTERPRETATION}

Davies \& Allison (2004a:95) label Matthew a "conservative redactor", but also a "creative writer". Yet Moule accuses Matthew's use of the Old Testament, remarking that Matthew ignored the original meaning of words and took them out of context. $\mathrm{He}$ considers Matthew's appeals to the Old Testament "manifestly forced and artificial and unconvincing" (Moule 1977:129). Van der Walt (1962:220), however, recognizes similar ways of interpretation in the other Sinoptics as well: "... (dit is) duidelik dat die verhouding profesie-vervulling ... geen reguit, egalige lyn sonder meer is nie. Die verhouding is materieel, nie soseer formeel nie, wesenlik, nie soseer na die letter van die verband nie, intrinsiekkwalitatief, nie soseer uitwendig-kwantitatief nie". Menken (2003:195) makes a general remark on the way of interpretation in Jewish and Christian circles in the time of the New Testament: "all

16 The Dead Sea Scrolls contain some possibly analogous collections of eschatological texts (Fitzmyer 1974:58-89). 
sorts of textual manipulations were also used in early Jewish and Christian circles to reduce the distance between the scriptural word and its alleged fulfilment ". He also writes that perfect correspondence between the old text and the new reality is very rare. Those who accept new beliefs would therefore find "means to reduce the cognitive dissonance caused by the imperfect correspondence between the old text and the new reality"17 (Menken 2003:198).

France (1998:182), however, points out that Matthew's method of using the Old Testament should be understood within Matthew's understanding of its fulfilment in Jesus. Matthew should rather be seen as an innovative theologian whose thoughts are controlled by his conviction of the climactic place of Jesus in the development of God's purpose in history. Matthew's interpretation is not based on a simplistic or atomistic correspondence between the quoted text and its fulfilment (Keener 1999:87). He recognized a further dimension of continued divine purpose of text, a sensus plenior which comes to light in ongoing revelation. Thus Matthew does not set the meaning of the original text aside, but places it in the wider context of divine actions ${ }^{18}$. Matthew's links between the Old Testament and the fulfilment in Jesus often are unexpected, but they emerge from the same God who acted in the history of Israel and spoke through the prophets and now brought his redemptive scheme to its end result. Matthew recognizes ongoing patterns in the work of God. Matthew's point is clear: Scripture reveals the divine plan, and those who trust its authority should not doubt any miracle it promises (Keener 1999:87).

A further comment is necessary here. It was often supposed that to perceive the relation between the Scriptures and the eschaton divine assistance was necessary. The eschatological meaning of the Jewish Bible was disclosed only by its fulfilment in Jesus and so appreciable only by those who believed in Jesus (cf. Matt. 11:25-27: "... you have hidden these things from the wise and learned, and

17 Surely those who rejected the new beliefs would have found in these imperfect correspondences an argument against the fulfilment citations as proof texts.

18 Van der Walt (1962:232) recognized a similar pattern in Jesus' references to the Old Testament in his public ministry, as He is described by all the Synoptic Gospels. 
revealed them to little children. Yes, Father, for this was your good pleasure. ... no one knows the Father except the Son and those to whom the Son chooses to reveal him").

\section{SIGNIFICANCE OF THE FULFILMENT MOTIF}

\subsection{Fulfilment in the Prologue}

Matthew makes his concern for fulfilment clear right from the beginning of his Gospel. "A man who begins his book about Jesus with a prologue like this can surely justly be said to be preoccupied with the theme of fulfilment" (France 1998:169). He starts off with the genealogy of Jesus (Mt. 1:1-17) for the obvious reason to link Jesus as direct as possible to the Old Testament. The echo of Genesis is noticeable in the first two words Bí $\beta \lambda o s \quad \gamma \in \nu \in$ É $\sigma \in \omega S$. He repeatedly mentions the names of Abraham and David, follows the royal line of Judah, and carefully structures the genealogy around the beginning and end of the monarchy of Judah. The symmetry as drawn out in verse 17 sets the impression that all, which has been done before, reaches its culmination in Jesus (France 1998:168; Viljoen 1006b:251).

The remainder of the prologue (Mt. 1:18-2:23) consists of a series of five short sketches, each with at least one explicit Old Testament quotation which is said to be fulfilled in a particular aspect of Jesus' birth and childhood narratives. All four stories in chapter 2 also refer to place names rooted in Scripture ${ }^{19}$ :

- Jesus' birth from a virgin and his significant name (Mt. 1:22-23 (= Is. 7:14)): Matthew's narrative of the virgin birth explains and exalts the character of the Lord. Matthew understands "God with us" in Isaiah 7:14 to mean that Jesus is truly God. Matthew appeals to his audience to worship Jesus as God who was born to relatively poor parents in a hostile world. The striking use of o̊ $\lambda$ ov further indicates that Matthew adduces the quotation not only for the sake of the name Immanuel, but because the entire story of the birth announcement should be viewed as fulfilment of Scripture (Luz 1990:121).

19 The fact that these citations refer to locations indicates the importance of these place names for Matthew (Stendahl 1995:71-72). Jesus is "forced to wander from place to place" (Schweizer 1975:41) as king of a world hostile to him. This promises little better for his followers (Mt. 10:17-39, 13:21; 16:2427; 24:9-14) (Keener 1999:109). 
- The visit of the wise men from the East and the identification of location where Jesus was born (Mt. 2:6 (= Mi. 5:120) $)^{21}$ : Contemporary Judaism regarded Micah's indication that the Messiah would come from Bethlehem. While the religious leaders knew where the Messiah would be born, they failed to join the Magi in their quest. Instead they indirectly became the collaborators of Herod.

- $\quad$ The escape to Egypt (Mt. 2:15 (= Hs. 11:1)): By quoting Hosea Matthew shows how Jesus has cut a new way through the wilderness to the land of promise. In Jesus the exodus from Egypt is repeated and completed (Floor 1969:36). God called his son Jesus to identify with the suffering of his people. In Jesus the anticipated new salvation of God's people had begun.

- Infanticide (Mt. 2:17-18 (= Jr. 31:15)): In sharp contrast to the escape of Jesus to Egypt (as fulfilment of Scripture), comes the episode of the infanticide in Bethlehem (also as fulfilment of Scripture). The introduction of the formula quotation is deliberately changed. Matthew uses the temporal Tó $\tau \epsilon$ to replace the purposive i $\nu \alpha$. The infanticide did not happen in order that ( $i \nu \alpha)$ the Scripture is fulfilled. It does not speak of the direct responsibility of God for the death of the children (Allison 2005:253; Luz 1990:147). Yet the quotation once again depicts the concept of God's plan. This fulfilment quotations laments injustice rather than creating an ideal story world in which it does not exist (Keener 1999:110). Matthew chooses an ancient lament from one of the most sorrowful times of his people's history. Rachel, who wept from her grave in Bethlehem during the captivity, was now weeping at a nearer crisis significant in salvation history (cf. Mt. 1:12, 17). In the New Testament only Matthew mentions Jeremiah by name, and at three places (Mt. 2:17; 16:14 and 27:9). Jeremiah

20 The wording of the quotation deviates from all known text forms of Mi. $5: 1$. It is a mixed quotation of which the closing sentence comes almost literally from $2 \mathrm{Sm}$. 5:2 (LXX). Matthew might have included the idea of the people of God (入aos) as an anti-Jewish allusion (Luz 1990:130).

21 Matthew 5:16 in the strict sense of the word does not contain a fulfilment quotation as the significant introductory word $\pi \lambda \eta \rho 0 \omega$ is absent. Matthew probably was unwilling to attribute the fulfilment formula to the hostile high priests and scribes (Luz 1990:130). 
was the prophet of doom and sorrow. It is therefore appropriate to link his name with tragic circumstances of Jewish opposition to Jesus (Davies \& Allison 2004a:267). Yet, the context in Jeremiah 31 also implies future hope. God comforts Rachel promising the restoration of his people (Jr. 31:15-17). The painful events of Jesus' persecuted childhood are the anvil on which God would fulfill the promises to his people. Israel's history points to Jesus, and God declares Jesus' solidarity with Israel. While his people lament, God reserved a promise of hope for his people (Keener 1999:112).

- $\quad$ Settling in Nazareth (Mt. 2:23) 22 : Matthew shows divine significance in the choice of Nazareth as Jesus' home town. Matthew accomplishes this by a word play, a common form of argumentation in both Jewish and Greco-Roman rhetoric (Keener 1999:114) ${ }^{23}$. It is easy to recognize that Matthew is making a play on the name Nazareth, but it is difficult to decide with which word he is playing. Some scholars argue that Matthew intended Nazirite and draws a typological application from Samson in Judges (Patte 1987:39; Meier 1980:16). An alternative would be that Matthew reads the Hebrew Nazir in light of Jesus as "holy to God" (Soares Prabhy 1976:205).

Quotations in Matthew's infancy narrative derive from passages stressing God's deliverance of his people from slavery. He evokes the Old Testament hope of salvation of God's people, including the justice and peace of God's kingdom (Keener 1999:97).

Besides the prominent quotations the narratives echo Old Testament stories. The birth and protection of Moses and the slaughter of the wicked king that failed to get rid of Israel's deliverer clearly are echoed in Jesus' birth narrative. Other echoes are obvious in the visit of the wise men to bring gifts to the son of David, as the queen of Sheba did. Even the gifts recall passages as example of reverence to come (Ps. 72:10-11, 15; Is. 60:4-6).

22 It is difficult to identify the passage Matthew refers to. The plural $\delta ı \grave{\alpha} T \hat{\omega} \nu \pi \rho о \phi \eta \tau \hat{\omega} \nu$ (Mt. 2:23) indicates that Matthew probably was not able to identify the quotation which he received.

23 Jewish exegesis commonly revocalized and repunctuated texts to yield new interpretations (Patte 1975:55). 


\subsection{Fulfilment in Jesus' ministry outside Jerusalem}

Matthew places Jesus ministry within the context of the fulfilment of Scriptures. At four strategic places in his narrative, he quotes from the Scriptures. These chapters describe an increasing antagonism of the Jewish leaders against Jesus, while Gentiles show a growing interest in Him.

- Jesus' Galilean ministry [Mt. 4:14-16 (= Is. 8:23-9:1)]: The wording of the formula quotation corresponds neither to the Hebrew, LXX or the Targum. It is closest to the Masoretic text ${ }^{24}$. The wording presupposes a Messianic interpretation of Isaiah 9:1-2. Matthew's concern obviously is to accentuate "Galilee of the Gentiles" which summarizes the four previous geographical settings (Luz 1990:193). Matthew cites Scripture probably to counter Judean opponents' ridiculing the Galilean origin of the Jesus movement. Even more importantly Matthew keeps urging that what Isaiah has said about Galilee foreshadows the Gentile mission (Keener 1999:146). In Galilee the risen Lord would give the disciples the command to make disciples of the Gentiles (Mt. 28:16-29). The future perspective of salvation to the Gentiles is precisely in agreement with God's plan. It is important for Matthew to show that salvation for the Gentiles is biblical in accordance to prophetic perspective. Jesus acted in obedience to the Scriptures. The passage Matthew refers to addresses the work of the Davidic Messiah indicating that he would work in Galilee "of the Gentiles".

- Healing was part of Jesus' mission [Mt. 8:17 (= Is. 53:4)]: Matthew cites Isaiah to demonstrate that Jesus' mission of healing fulfills the character of the mission or the suffering servant who would restore Israel eschatologically. The quotation emphasizes that Jesus has the authority to heal as Israel's Messiah. It is important for Matthew to show that this plan corresponds with God's plan as predicted by the prophet (Luz 2001:14).

- The Spirit-anointed humble servant [Mt. 12:17-21 (= Is.42:14)]: Matthew quotes from Isaiah to indicate that Jesus is the

24 In the first part the quotation is abbreviated by omitting all verbal statements, shifting the weight to the second part of the quotation. 
"Messiah of Yahwe". The passage looks forward to the conflict in the following narrative where Jesus' opponents misinterpret his identity. Matthew quotes more than the "Spirit-endowed" or "chosen servant" to emphasize the humble character of Jesus and in the final line her reinforces the theme of the Gentile mission. While the Jewish people reject Jesus, the Gentiles will hope in Jesus. Matthew uses a $\operatorname{long}^{25}$ and important quotation here in the middle of the Gospel at a point in his narrative where the separation from Israel begins (Luz 2001, 191).

- $\quad$ Jesus' parables reveal God's long hidden mysteries [Mt. 13:35 (Ps. 78:2) $]^{26}$ : The formula quotation brings Jesus' public discourse to an emphatic closure. Israel's lack of understanding is such an important matter that Matthew uses a formula quotation to show how Jesus' parables discourse corresponds with God's will (Luz 2001:265). While the parables remain riddles to the outsiders, they conveyed God's hidden revelation to his followers (Keener 1999:389).

\subsection{Fulfilment in Jesus' ministry in Jerusalem}

Matthew once again places Jesus ministry within the context of the fulfilment of Scriptures. When describing Jesus' ministry in Jerusalem during the Passion Week, Matthew twice and at strategic places quotes from the Scriptures. These chapters are characterized by the increasing hostility of the Jewish leaders which climactically leads to the crucifixion of Jesus. When entering Jerusalem, the goal of Jesus' journey, Matthew indicates how Jesus thereby yet again fulfils key prophecies. When reflecting on the betrayal of Jesus, he even recognizes that the hostility of the Jewish leaders formed part of the plan of God.

- Jesus' lowly entry into Jerusalem [Mt. 21:4-5 (= Is. 62:11; Zch. 9:9) $]^{27}$ : Matthew narrates Jesus' lowly entry into Jerusalem, interrupting himself to place this event under the idea of the fulfilment of Scripture. A prophetic prediction which the rabbis also interpreted messianically (Luz 2005:7) is

25 It is the longest quotation Matthew has used.

26 Matthew cites the Psalmist as a prophet.

27 Matthew's first clause may derive from Is. 62:11. Conflation of texts was common practice (France 1985:298). 
fulfilled in Jesus' entry. The Jewish contemporaries might have chosen a more militant steed for their Messiah's entry, but Jesus chose an animal that would convey a lowly image. Matthew (and John) recognized this source of Jesus' allusion by explicitly citing the text from Zachariah. Jesus was announcing that He indeed was a king, but not a warrior king. Jesus alludes to images form Greco-Roman kings' triumphal entry into a conquered city, but employs them ironically (Davies \& Allison 2004c:120; Keener 1999:493). He would abolish war chariots and weapons in bringing peace to the nations (Luz 2005:8).

- The acceptance of Judas' blood money by the chief priests [Mt. 27:9-10 (Zch. 11:12-13; Jr. 18:3; 59:6-9)]: Matthew inserts a fulfilment citation here to reveal how the high priests and elders were guilty of the death of Jesus (Luz 2005:475). The quotation does not refer to Judas' betrayal, but to what they did. Once again it shows how the entire story of Jesus, including his passion, is part of God's plan. As in Matthew 2:17 Matthew uses the temporal Tó $\tau \in$ to replace the purposive $i \nu a$. This formula quotation introduces texts attached to stories in which evil is suffered because of opposition to Jesus. Such evil and its cause Matthew cannot attribute directly to the hand of God (Davies \& Allison 2004a:266). Matthew quotes Zechariah $11: 13$ as if "potter" (yoser) could be "treasury" ('oser). He revocalizes to provide a new interpretation, as

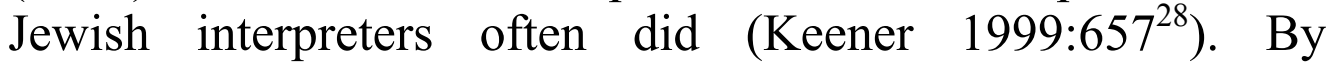
appealing to "Jeremiah" rather than to "Zechariah" Matthew probably reapplies Zechariah's prophecy with a message of Israel's coming restoration in Jeremiah. The narrative emphasis the guilt of the priests more than that of Judas. Matthew plays on the hypocrisy of the of the chief priests, who were willing to pay out blood money for Jesus' capture and

28 Luz (2005:468) assumes that the form of this unusual Zechariah quotation with its Jeremiah sounding addition might have been pre-Matthean. Prior to Matthew there must already have been an interplay between the death of Judas and the traditional fulfilment quotation. 
were willing to allow Judas' suicide, but too pious to accept their own blood money into the temple treasury ${ }^{29}$.

\section{CONCLUSION}

Matthew emphasises that God accomplishes his divine plan in Jesus. By the significant use of fulfilment formulae Matthew finds implicit truth about Jesus through out the Jewish Scriptures explaining how these quotations apply to Him. He places the fulfilment formulae at strategic places through out his Gospel making his concern for fulfilment clear through out.

The motif of fulfilment is very significant in the prologue. Matthew structures the narrative of Jesus' birth and childhood by ways of indirect and direct references to the Jewish Scriptures. Thus he emphasizes that Jesus - according to the Scriptures - came to save God's people from their sins. Yet, right from the beginning the suspicion of the Jewish religious leaders against Jesus becomes apparent, while gentiles show interest in Jesus' person and word. When starting his description of the public ministry of Jesus, Matthew strategically begins with a fulfilment quotation to show that the salvation for the gentiles (an idea which was ridiculed by the Jewish leaders) is in accordance to prophetic perspective. While describing the growing disillusionment of the Jews against Jesus, Matthew at several places refers to the Scriptures. He argues that Jesus ministry corresponds with God's plan as predicted. Matthew uses the longest and very important quotation in the middle of his Gospel when the Jewish people openly start to reject Jesus, while the Gentile people are putting their hope in Jesus. Matthew brings the public discourse about the Jews' lack of understanding to an emphatic closure with yet another fulfilment quotation. Matthew also starts his description of the Passion Week by quoting from Scripture to identify Jesus' allusion of a lowly entry into Jerusalem. The author climactically ends with a formula quotation by which he exposes the wickedness of the Jewish religious leaders for accepting Judas' blood money.

Matthew uses the formula quotations as tool internally to encourage the Christian community to understand their faith in context of the God of Israel and externally to justify his

29 The chief priests acknowledge that the money is in fact "blood money", and that they have paid for the murder of an innocent man (Patte 1987:377). 
communities' convictions about Jesus. He bases his argumentation effectively on the mutual conviction that the Jewish Scriptures are authoritative and need eschatological fulfilment. Though Matthew's use of the Jewish Scripture sometimes seems to be forced to the modern reader, he utilizes the acceptable Targumist hermeneutical method of his time according to which paraphrasing and interpolation were acceptable to bring out the perceived sensus plenior of the quotation.

Matthew emphasizes that the life of Jesus fulfilled God's purposes as previously revealed in his Scriptures. With the fulfilment quotations Matthew persuasively and systematically places the life and ministry of Jesus in the unfolding plan of God. The entire story of Jesus, including the opposition and pain that He had suffered, forms part of God's plan.

\section{Consulted literature}

Albl, M C 1999. "And Scripture cannot be broken": The form and function of the Early Christian Testamonia Collections. Leiden: Brill (Novum Testamentum Supplementum Series 96).

Allison, D C 2005. Studies in Matthew Interpretation: Past and present. Michigan: Baker Academic.

Burridge, R A 1994. Four Gospels, one Jesus? Grand Rapids: Eerdmans.

Carter, W 2000. Matthew and the Margins:. A socio-political and religious reading. Sheffield : Academic Press. (Journal for the Study of the New Testament Supplement Series 204).

Combrink, H J B 1997. The Gospel according to Matthew: Introduction and Theology, in Du Toit, A B (ed.), Guide to the New Testament IV. The Synoptic Gospels and Acts: Introduction and Theology. Halfway House: Orion, 57-101.

Davies, W D \& Allison, D C 2004a. Matthew 1-7. Volume 1. International Critical Commentary. London \& New York: T \& T Clark.

-, 2004b. Matthew 8-18. Volume 2. International Critical Commentary. London \& New York: T \& T Clark.

-, 2004c. Matthew 19-28. Volume 3. International Critical Commentary. London \& New York: T \& T Clark.

Dodd, C H 1952. According to the Scriptures: The substructure of New Testament Theology. London: Nisbet.

Ellis, E E 1991. The Old Testament in Early Christianity: Canon and Interpretation in the Light of Modern Research. Tübingen: Mohr. 
Evans, C A 2004. The Old Testament in the New. in S McKnight \& G R Osborne (eds.), The Face of the New Testament Studies: A Survey of Recent Research. Grand Rapids: Baker Academic, 130-145.

Floor, L 1969. De nieuwe exodus. Representatie en inkorporatie in het Nieuwe Testament. Potchefstroom: PU vir CHO.

Fitzmyer, J A 1974. Essays on the Semitic Background of the New Testament. Missoula: Scholars Press.

France, R T 1980/1. The Formula-Quotations in Matthew 2 and the Problem of Communication. New Testament Studies, 233-251.

-, 1985. Matthew. Tyndale New Testament Commentaries. Grand Rapids: Eerdmans.

-, 1998. Matthew: Evangelist and teacher. Illinois: Intervarsity Press.

Gloer, H 1991. Old Testament Quotations in the New Testament, in T C Butler (ed.), Holman Bible Dictionary. Nashville: Broadman \& Holman, 2-11.

Gundry, R H 1967. The use of the Old Testament in St. Matthew's Gospel, with special reference to the Messianic hope. Leiden: Brill.

Harris, J.R. 1916-1920. Testimonies. Cambridge: University Press. (2 Volumes.)

Hays, R B 1989. Echoes of Scripture in the Letters of Paul. New Haven: Yale University Press.

Horbury, W 1982. The Benediction of the Minim and early Jewish Christian controversy. Journal of Theological Studies 33, 19-61.

Juel, D 1988. Messianic Exegesis: Christological Interpretation of the Old Testament in Early Christianity. Philadelphia: Fortress Press.

Keener, G S 1999. A commentary on the Gospel of Matthew. Michigan \& Cambridge: Eerdmans.

Kooyman, A C 1992. De joodse konteks van Mattheüs 5:31-32: Een bijdrage aan het debat over het gebruik van rabbijnse teksten voor de bestudering van het Nieuwe Testament. Utrecht: Rijksuniversiteit.

Lindars, B 1961. New Testament Apologetic: The Doctrinal significance of the Old Testament Quotations. London: SCM.

Loader, W R G 1997. Jesus' attitude towards the Law: A study of the Gospels. Tübingen: Mohr Siebeck (Wissenschaftliche Untersuchungen zum Neuen Testament 2. Reihe).

Luz, U 1990. Matthew 1-7. A commentary. Edinburgh: T \& T Clark.

-, 2001. Matthew 8-20. A commentary. Mineapolis: Fortress Press.

-, 2005. Matthew 21-28. A commentary. Mineapolis: Fortress Press. 
Meier, J P 1980. Matthew. New Testament Message 3. Wilmington: Michael Glazier.

Menken, M J J 1997. The source of the quotation from Isaiah 53,4 in Matthew 8:17. Novum Testamentum 39, 313-327.

-, 1998a. The textual form of the quotation from Isaiah 8,23-9,1 in Matthew 4,15-16. Revue Biblique 105, 526-545.

-, 1998b. The quotation from Isaiah 42,1-4 in Matthew 12, 18-21: Its relation with the Matthean context. Bijdragen 59, 251-266.

-, 1999. The Greek translation of Hosea 11,1 in Matthew 2,15: Matthean or pre-Matthean. Filología zum Neuen Testament 12, 79-88.

-, 2000. The Quotation from Jeremiah 31(38), 15 in Matthew 2,18: A study of Matthew's Scriptural text. Journal for the Study of the New Testament (Supplementum) 189, 106-125.

-, 2001a. The textual form or the quotation from Isaiah 7,14 in Matthew 1,23. Novum Testamentum 43, 144-160.

-, 2001b. The sources of the Old Testament quotation in Matthew 2:23. Journal of Biblical Literature 120, 451-468.

-, 2003. Fulfilment of Scripture as a propaganda tool in early Christianity, in $\mathrm{P}$ W van der Horst, M J J Menken, J F M Smit, G van Vijen (eds.), Persuasion and discussion in early Christianity, Ancient Judaism and Hellenism. Leuven: Peeters CBET 33, 179-198.

-, 2004. Matthew's Bible. The Old Testament text of the Evangelist. Leuven: University Press.

Moule, C F D 1967/8. Fulfilment words in the New Testament: Use and Abuse. New Testament Studies 14, 293-320.

-, 1977. The origin of Christology. Cambridge: University Press.

Müller, M 2001. The reception of the Old Testament in Matthew and LukeActs: From interpretation to proof from Scripture. Novum Testamentum, 43(4), 315-330.

Obermann, A 1996. Die christologishe Erfüling der Schrift im Johannesevangelium: Eine Untersuchung zur johanneisschen Hermeneutik an hand der Schriftzitate (WUNT 2/83). Tübingen: MohrSiebeck.

Patte, D 1975. Early Jewish Hermeneutic in Palestine. Society of Biblical Literature Dissertation Series 22. Missoula: Scholars Press.

-, 1987. The Gospel according to Matthew: A Structural Commentary on Matthew's Faith. Philadelphia: Fortress Press.

Plummer, A 1982[1909]. An exegetical commentary of the Gospel according to st. Matthew. Grand Rapids: Baker. 
Schweizer, E 1975. The Good News according to Matthew. Atlanta: John Knox.

Sim, D C 1998. The Gospel of Matthew and Christian Judais: The Historical and social setting of the Matthean Community. Studies of the New Testament and its world. Edinbrugh: T \& T Clark.

Slingerland, H D 1979. The Transjordan origin of st Matthew's Gospel. Journal for the Study of the New Testament 3, 18-28.

Soares Prabhu, G M 1976. The Formula Quotations in the infancy narrative of Matthew. Rome: Biblical Institute Press.

Stanton, G N 1985. The origin and purpose of Matthew's Gospel. Matthean scholarship from 1945- to 1980, in H Temporini, \& W Haase (eds.). Aufstieg und Niedergang de römischen Welt, Teil II, Band 25, Teilband 3. Berlin: De Gruyter, 1889-1951.

Stendahl, K 1968. The School of St. Matthew. Philadelphia: Fortress.

-, 1995[1960]. Quis et unde? An analysis of Matthew 1-2, in G N Stanton (ed.). The interpretation of Matthew: Studies in New Testament interpretation. Edinburgh: T \& T Clark, 69-80.

Strecker, G 1971. Der Weg der Gerechtigkeit: Untersuchung zur Theologie des Matthäus. Göttingen: Vandenhoeck \& Ruprecht.

Van Bruggen, J 1990. Matteüs. Het evangelie voor Israël (Commentaar op het Nieuwe Testament). Kampen: Kok.

Van der Walt, T Die Koninkryk van God - Naby! Eksegetiese verkennings van die toekomsperspektief van Jesus Christus volgens die getuienis van die Sinoptiese Evangelies. Kampen: Kok.

Versteeg, J P 1980. Evangelie in viervoud: Een karakteristiek van de vier evangeliën. Kampen: Kok.

Viljoen, F P 2006a. Jesus' teaching on the Torah in the Sermon on the Mount. Neotestamentica 40(1), 135-156.

-, 2006b. The Matthean community according to the beginning of his Gospel. Acta Theologica 26(2), 242-262. 